\title{
Growth responses of Sphagnum hollows to a growing season lengthening manipulation in Alaskan Arctic tundra
}

\author{
H. Genet $\cdot$ S. F. Oberbauer $\cdot$ S. J. Colby $\cdot$ \\ C. L. Staudhammer • G. Starr
}

Received: 4 April 2012/Revised: 15 July 2012/Accepted: 14 August 2012/Published online: 30 August 2012

(C) The Author(s) 2012. This article is published with open access at Springerlink.com

\begin{abstract}
The global increase in surface air temperature has produced an overall lengthening of the growing season by $3-5$ days/decade in the Northern Hemisphere during the last 30 years. The direct impact of a longer growing season has not been well documented for Sphagnum moss communities in the Arctic. We hypothesized that an increase in the growing season length may be detrimental to Sphagnum growth as a result of photoinhibition caused by the plants emerging from snow near the seasonal peak of solar irradiance. We conducted an experiment from 1999 to 2002, lengthening the growing season in arctic Alaska, to determine the effects that this simulation of climate change had on the growth of hollows dominated by Sphagnum angustifolium. The lengthened growing season was associated with a decrease in annual moss height increment of 78 and $69 \%$ for 1999 and 2000, respectively. These growth reductions may be related to freeze/thaw episodes and prolonged periods of cold in those years. The growth of individuals exposed to snow removal was also reduced by high global radiation. Overall, snow removal did not significantly affect the seasonal dynamics of growth, but seasonal patterns of growth strongly differed among years. These differences in seasonal dynamics suggest that
\end{abstract}

H. Genet · C. L. Staudhammer · G. Starr ( $\square)$

Department of Biological Sciences, University of Alabama,

Tuscaloosa, AL 35487, USA

e-mail: gstarr@ua.edu

Present Address:

H. Genet

Institute of Arctic Biology, University of Alaska,

Fairbanks, AK 99775, USA

S. F. Oberbauer · S. J. Colby

Department of Biological Sciences, Florida International

University, Miami, FL 33199, USA
Sphagnum growth is driven by opportunistic responses to favorable conditions rather than ontogenetic drivers. In addition, we compared environmental variation and growth between control and snow removal plots. Growth of Sphagnum in both treatments was stimulated by warmer soil temperatures and drier conditions. With earlier snowmelt as a result of warmer temperatures, it is likely that S. angustifolium will be subjected to higher levels of radiation and possibly greater photoinhibition which may lead to lower growth rates and significant implications for moss production in tussock tundra.

Keywords Acclimatization - Climate change . Peat moss · Productivity $\cdot$ Snowmelt $\cdot$ Lengthened growing season $\cdot$ Toolik Field Station

\section{Introduction}

The global increase in surface air temperature that started at the end of the nineteenth century (IPCC 2007) has been shown to be amplified at high latitudes (Overland et al. 2004). In one such high latitude region, air temperatures for the North Slope of Alaska have increased by $2.9^{\circ} \mathrm{C}$ since 1976, which is three times the global average (Wendler et al. 2010). This temperature increase has lead to a lengthening of the growing season by approximately $3-5$ days/decade for the last three decades (Tedesco et al. 2009). In many areas of the Arctic, snowmelt initiates the beginning of the growing season; in the absence of snow cover, temperatures and radiation levels are sufficient for plant growth and physiological activity (Oberbauer et al. 1998; Starr et al. 2000, 2008). Earlier snowmelt may induce a deeper thaw of the permafrost, and earlier snowmelt occurring around the summer solstice can 
strongly increase the light quantities reaching the vegetative communities. This additional light may alter energy and hydrological budgets (Benoy et al. 2007) and has implications for plant photosynthetic activity (Myneni et al. 1997; Starr et al. 2008), productivity (Chapin et al. 1996), and species interactions and composition (Galen and Stanton 1995; Wipf and Rixen 2010).

Although the effects of snow cover on vascular plants have been evaluated to some degree (Wipf and Rixen 2010), the response of Sphagnum species remains largely overlooked. This deficiency is in part related to the gaps in our understanding of Sphagnum growth processes. Only a few studies have described the seasonal growth dynamics of northern peat mosses (Clymo and Hayward 1982; Murray et al. 1989; Gehrke 1998; Sonesson et al. 2002). Understanding their growth processes becomes even more important with the growing evidence that northern systems are changing at extremely rapid rates.

Developing a better understanding of northern peatlands is a critical need given that one-third of the world's soil organic carbon (Gorham 1991) is found in these ecosystems and has been shown to be very susceptible to environmental changes. In a subarctic blanket-bog in Northern Sweden, warming of approximately $1{ }^{\circ} \mathrm{C}$ induced a persistent increase in ecosystem respiration rates, with a $60 \%$ increase in spring and $52 \%$ in summer over 8 years (Dorrepaal et al. 2009). As Sphagnum is a principal peat producer, a better understanding of the environmental drivers of Sphagnum productivity is of key importance to predicting the fate of peat communities in high latitude ecosystems.

Previous studies have shown that increased air temperatures associated with early snowmelt may induce an increase of Sphagnum biomass productivity (Sonesson et al. 2002; Dorrepaal et al. 2004; Breeuwer et al. 2008). However, a lengthened growing season can lead to water stress resulting from a deeper thaw of permafrost which may have a negative effect on Sphagnum productivity (Benoy et al. 2007; Starr et al. 2008). Given the sensitivity of Sphagnum spp. to high light intensity (Harley et al. 1989; Murray et al. 1989, 1993), growth responses to early snowmelt may be limited by photoinhibition or photooxidation. This limitation may be enhanced by increased risks of frost damage early in the growing season (Benoy et al. 2007). Earlier snowmelt may also increase the exposure of peat mosses to UV-B radiation that can be detrimental to growth; however, the few studies focused on this question produced conflicting results (Gehrke 1998; Sonesson et al. 2002; Robson et al. 2003). Earlier snowmelt and lengthened growing season might induce significant changes in the growth response of Sphagnum species to climate, though long-term studies have demonstrated the high capacity of Sphagnum species to maintain their population for several decades to several centuries (Rydin and Barber 2001; Gunnarsson et al. 2002). These results imply that Sphagnum species have a high capacity to cope with environmental variability and a high level of acclimatization through mechanisms of resistance (Zona et al. 2011).

To advance our understanding of the effects of earlier snowmelt on the seasonal growth of Sphagnum, we mimicked a lengthened growing season via a 4-year snow removal experiment in an acidic tussock tundra ecosystem near Toolik Lake Research Station in Arctic Alaska. The objectives of the study were to test the impact of snow removal on: (1) the annual height increment, (2) the seasonal dynamics of height growth, and (3) the height growth response to climate.

\section{Materials and methods}

Study site

This study was conducted near Toolik Field Station $\left(68^{\circ}\right.$ $38^{\prime} \mathrm{N}, 149^{\circ} 34^{\prime} \mathrm{W}, 760 \mathrm{~m}$ above sea level), in association with a larger ecosystem-level season extension experiment started in 1995 (Oberbauer et al. 1998) as part of the International Tundra Experiment (ITEX). The station is located on the edge of Toolik Lake in the northern foothills of the Brooks Range, Alaska. The experiment was conducted on the northeastern side of a $10^{\circ}$ slope. The vegetation community of the site was a moist tussockdwarf-shrub tundra (Bliss and Matveyeva 1992) typical of the Alaskan Arctic consisting of graminoids (mainly Eriophorum vaginatum and Carex bigelowii), deciduous shrubs (mainly Betula nana with Vaccinium uliginosum and Salix pulchra), evergreen shrubs (mainly Ledum palustre and Vaccinium vitis-idaea), and mosses (primarily Sphagnum spp., Hylocomium splendens, Aulacomnium turgidum, and Dicranum spp.,). Sphagnum is most developed in dense patches between graminoid tussocks. The climate is continental arctic, with mean monthly temperatures ranging from -22.5 (January) to $11.2{ }^{\circ} \mathrm{C}$ (July), and annual precipitation of $248 \mathrm{~mm}$ over the period from 1989 to 2007 (Environmental Data Center, Toolik Field Station, http://toolik. alaska.edu/edc/). The soils are Pergelic Cryaquepts developed on Itkillik glacial till.

For the experiment, twelve plots, $\sim 50 \mathrm{~cm}$ in diameter, were established in August 1998 around hollow patches ( $\sim 15-30 \mathrm{~cm}$ in diameter) dominated by Sphagnum angustifolium mixed with some S. girgensohnii. Half of the plots were randomly assigned as controls and half as early snow removal treatments. From 1999 to 2002, the growing season was extended on the six experimental plots by careful removal of loose snow down to the moss layer on 3 May, approximately 2-4 weeks before natural snowmelt 
Table 1 Timing of full snowmelt on snow removal plots and natural snowmelt on control plots, and soil and air temperatures averaged during the spring treatment period for 1999-2002

\begin{tabular}{|c|c|c|c|c|c|}
\hline Years & Date of melt on snow removal (DOY) & Date of natural snowmelt (DOY) & Extended season (days) & $T_{\text {air }}\left({ }^{\circ} \mathrm{C}\right)$ & $T_{\text {soil }}\left({ }^{\circ} \mathrm{C}\right)$ \\
\hline 1999 & 125 & 139 & 14 & $0.63(4.66)$ & $-3.40(3.30)$ \\
\hline 2000 & 142 & 159 & 17 & $0.65(7.15)$ & $-3.22(2.37)$ \\
\hline 2001 & 125 & 157 & 32 & $-3.91(6.40)$ & $-4.77(3.06)$ \\
\hline 2002 & 131 & 142 & 11 & $3.19(6.20)$ & $-1.21(1.71)$ \\
\hline
\end{tabular}

Standard deviations are indicated in parenthesis

$D O Y$ day of year, $T_{\text {air }}$ mean air temperature, $T_{\text {soil }}$ mean soil temperature

(Table 1). As the plots were located in hollows, moss capitula were frequently encased in ice or hard-packed snow. This ice or hard-packed snow was left in place and allowed to melt, as mechanical removal may have caused considerable damage to the moss mats. Following initial snow removal, the plots (open depressions in the snow) were left exposed to ambient conditions for complete thawing (Table 1). In the event of advancing storm fronts or winds, plots were covered with a transparent fiberglass sheet to prevent additional snow deposition (Starr et al. 2008). Melt of the ice or hard-packed snow was scored daily to identify the date when all of the Sphagnum in the patch were completely free of snow and ice. This was compared to our control plots to determine the extent of our manipulation of the growing season for each year of the study (Table 1).

\section{Growth measurement}

To measure apical growth of Sphagnum, we used the cranked-wire technique (e.g., Clymo 1970; Sonesson et al. 2002; Dorrepaal et al. 2004; Breeuwer et al. 2009), which measures the capitula height relative to a fixed point on the wire. Four individuals per plot were measured for growth by carefully recording the distance between the top of the Sphagnum capitula and the top of its associated wire, to the nearest $0.5 \mathrm{~mm}$. Points shaded by vascular plants were avoided. We limited the measurements within each plot to four individuals due to the restricted space (total area of the moss mat) that was available to install cranked wires into the organic soils. Each year, height measurements were taken at least five times during the growing season, around 11 June ( \pm 3 days), 23 June ( \pm 2 days), 9 July ( \pm 4 days), 19 July ( \pm 1 day), and 3 August ( \pm 1 day). We defined the growing season as the time between natural snowmelt and leaf yellowing of deciduous vascular plants. During years when the growing season was naturally longer, we added additional measurements to span the entire season, which included May 24, 2002 and August 18, 2000. These additional measurements were only used to compute the annual height increment (AHI) achieved during the entire growing season, computed as the difference between the height measured at the end of the growing season and the height measured at the beginning of the growing season. The wires were left in place during winter. Because of possible movements due to successive freezing/thawing episodes, changes in height occurring during winter were not included in growth calculations (Dorrepaal et al. 2004). The seasonal variation of growth was characterized by the seasonal growth rates (SGR), computed as the ratio of the difference of height between two consecutive measurements to the time (in days) between these two consecutive measurements. We excluded 1999 data from our analysis of SGR because time intervals between height measurements were much longer than in other years (4.5 weeks). The impact of snow removal on $S$. angustifolium was tested on an annual basis with $\mathrm{AHI}$ and on a seasonal basis with SGR. Other methods of quantifying the experimental treatment, such as quantifying bulk density or taking physiological measurements, were not used, as they require destructive harvest, and due to the small area available for study would have limited our ability to conduct this study in the same area over the 4 years. While this approach does present some limitations, it allows us to gain insights into the growth and survival of Sphagnum in acidic tussock tundra over a longer-term than has been done in previous studies.

\section{Environmental data}

Daily mean air temperature $\left(T_{\text {air }}\right.$, in $\left.{ }^{\circ} \mathrm{C}\right)$, total precipitation (P, in $\mathrm{mm} /$ day), and total global radiation (GR, in $\mathrm{J} / \mathrm{cm}^{2} /$ day $^{1}$ ) were acquired from the micrometeorological station of the Long-Term Ecological Research Project (LTER) terrestrial site, located southwest of Toolik Field Station approximately $500 \mathrm{~m}$ northwest of our manipulation. To avoid damage to Sphagnum mats and disturbance of the cranked wires that may have occurred with the insertion of soil moisture and temperature probes, soil moisture (Moist) and soil temperature were measured in the ecosystem 
experiment adjacent to the moss plots. These plots $(n=6$ plots per treatment) were approximately $\sim 10-20 \mathrm{~m}$ west of our manipulation, where snow was removed 1-2 days prior to snow removal on the moss plots. In a preliminary experiment on the ecosystem plots where cranked wires and soil probes were simultaneously used for measurements, we found an unacceptable level of disturbance to wires, and thus, these plots were only used to obtain data from soil probes. Soil moisture was measured using Campbell CS615 water content reflectometers (Campbell Scientific Inc., Logan, UT, USA) placed at $45^{\circ}$ with respect to the soil surface, thereby integrating soil moisture across the top $20 \mathrm{~cm}$ of soil $(n=6)$. The CS615 sensors were not calibrated for the specific soil type at the site; thus, reported values are relative estimates of volumetric water content. These measurements were taken twice weekly. Soil temperatures were collected at $5-\mathrm{cm}$ depths in each of the plots using copper-constantan thermocouples with a Campbell 21X datalogger and AM25T solid state multiplexer (Campbell Scientific Inc., Logan, UT, USA; Starr et al. 2008). Soil temperature measurements were taken every minute and recorded as hourly averages (Starr et al. 2008).

For the analysis of Sphagnum growth response to climate, we averaged climatic parameters over each time interval between consecutive measurements (winter excluded). Previous studies from interior Alaska have shown that the positive effect of a rain event depends on the length of the preceding dry period (Skre and Oechel 1981). Therefore, the proportion of dry days (PDD), that is, days without precipitation, was computed. Also, to take into account the sensitivity of mosses to freezing events (Kennedy 1993), the proportion of days with negative daily temperature (PND) was computed for each measurement period.

\section{Data analyses}

The effect of snow removal on soil moisture, AHI, and SGR were tested over time using a mixed effects model that explicitly accounted for the repeated measures nature of the data with an autocorrelated variance-covariance structure. The models for AHI and SGR included fixed effects for treatment and time of measurement and also included a random effect to account for the relationship among individuals measured in the same plot, since height growth measurements of individuals belonging to the same plot are likely correlated. The model describing the effect of snow removal on AHI (Model 1) used year as the time of measurement, whereas the model describing the effect of snow removal on SGR (Model 2) used year and day of year (DOY). All two-way (Model 1) and three-way (Model 2) interactions were included. To further explore the significant interactions, the effect of the snow removal was tested
Table 2 Pearson correlation coefficients among climatic variables, averaged between successive measurements, from 1999 to 2002

\begin{tabular}{lrccccc}
\hline & \multicolumn{1}{l}{$T_{\text {air }}$} & \multicolumn{1}{l}{$T_{\text {soil }}$} & GR & Moisture & P & PND \\
\hline$T_{\text {soil }}$ & $\mathbf{0 . 8 2 4}$ & & & & & \\
GR & $\mathbf{0 . 2 1 9}$ & $\mathbf{- 0 . 2 3 0}$ & & & & \\
Moisture & $-\mathbf{0 . 1 5 7}$ & 0.0252 & $\mathbf{- 0 . 4 1 0}$ & & & \\
P & $\mathbf{- 0 . 1 8 7}$ & -0.058 & $\mathbf{- 0 . 3 6 3}$ & $\mathbf{0 . 3 4 2}$ & & \\
PND & $\mathbf{- 0 . 7 0 2}$ & $\mathbf{- 0 . 5 5 2}$ & $\mathbf{0 . 1 2 9 3}$ & $\mathbf{0 . 2 0 7}$ & $\mathbf{0 . 1 9 1}$ & \\
PDD & $\mathbf{0 . 2 8 0}$ & $\mathbf{0 . 3 8 0}$ & $\mathbf{0 . 2 6 0 8}$ & $\mathbf{- 0 . 4 5 5}$ & $\mathbf{- 0 . 6 1 3}$ & 0.006 \\
\hline
\end{tabular}

Significant coefficients $(p$ value $<0.05$ ) are marked in bold

$P$ precipitation, $T_{\text {air }}$ mean air temperature, $T_{\text {soil }}$ mean soil temperature, $G R$ global radiation, Moisture soil moisture, $P N D$ proportion of freezing days, $P D D$ proportion of days without precipitation

within each year, using an analysis of simple effects. All analyses were performed using the SAS statistical package (SAS 9.1, SAS Institute Inc., Cary, NC, USA). The assumptions of normality and homoscedasticity were verified by examining residual plots. Effects were considered highly significant at the 0.05 level and marginally significant at 0.15 .

To quantify the response of SGR to climate, we developed a model of SGR with the set of daily climatic variables averaged between measurements as the input variables. While these variables did not exhibit significant autocorrelation (results not shown), Pearson correlation coefficients computed with pairwise combinations of these climatic variables did show significant intercorrelations among variables (Table 2). To avoid statistical issues associated with multicollinearity among independent variables (e.g., overestimation of regression coefficients and their standard errors; Fekedulegn et al. 2003), we performed a principal components regression. Following the methods of Fekedulegn et al. (2003), we used principal components analysis to transform the set of climatic variables into a new set of uncorrelated variables (principal components; PCs) and retained the first four components. Because the PCs are orthogonal, they are independent and an ordinary least square multiple regression analysis of the response variable (SGR) was then performed against the first four PCs. Once the regression coefficients for the reduced set of orthogonal variables were calculated, they were then back-transformed into a new set of coefficients that corresponded to the initial correlated set of variables (Model 3). The impact of snow removal on Sphagnum growth response was then tested on the residuals of Model 3 , which indicated the impact of the treatment, given that the climatic variables have already been accounted for. To further illuminate climatic drivers, we repeated the principal components regression, making a separate analysis for each treatment to identify potential differences in the factors affecting growth response to climate by treatment. 


\section{Results}

Snow removal on the treatment plots took place on a fixed date (DOY 123), but depending on spring weather conditions, complete melt of the plots occurred from 2 to 19 days later (Table 1). Snowmelt on control plots occurred from 11 to 32 days after complete melt on snow removal plots, with the longest treatment duration occurring in 2001. The snow removal plots were subjected to 21 consecutive days of freezing air temperatures in 2001 versus only 4 days in 2002 and 6 days in 2000 (Fig. 1). In 1999, after 4 consecutive days of freezing temperatures, temperatures rose above zero for 6 days before dropping again below freezing for 3 consecutive days (Fig. 1). In 2002, spring temperatures during the treatment period were warmer than in 1999-2001 (Table 1), but the overall growing season mean was the coolest for the study period (Table 3), in part as a result of a series of freeze events during the growing season (Fig. 1). There was no significant effect of snow removal on soil moisture $(p=0.780$ results not shown).

The model for annual height increment (AHI; Model 1) indicated that there was a significant treatment by year interaction, meaning that the effect of snow removal on
AHI was different among years ( $p=0.045$; Table 4$)$. The simple effects analysis showed that AHI in control plots was marginally significantly higher than that of snow removal plots in years 1999 and 2001 ( $p=0.107$ and 0.085, respectively; Table 4; Fig. 2). Plots became snow free earliest in 1999 and 2001, and the treatment period was the longest in 2001 (Table 2).

Snow removal had no significant impact on seasonal growth rate (SGR; Model 2); the only significant effect in the model of SGR was the year by DOY interaction (Table 4). The significant interaction between year and DOY indicates that SGR changed significantly over the growing season, but the pattern of variation was significantly different among years (Fig. 3). The minimum SGR values were recorded at the beginning of the growing season in 2000 and 2002 and at the end of the season in 2001, whereas the maximum SGR values were recorded in the middle of the season in 2000 and 2001 and at the end of the season in 2002. Further investigation of the 3-way interaction between treatment, year, and DOY indicated that growth rates were much higher in snow removal plots at day 200 in 2000 and 2002 (Fig. 3).

The initial principal components regression analysis of SGR with climatic variables revealed a significant positive
Fig. 1 a Daily mean air temperature and $\mathbf{b}$ daily mean soil temperature, from snow removal to the end of the growing season, from 1999 to 2002. The horizontal bars indicate the period between snowmelt in snow removal plots and snowmelt in control plots
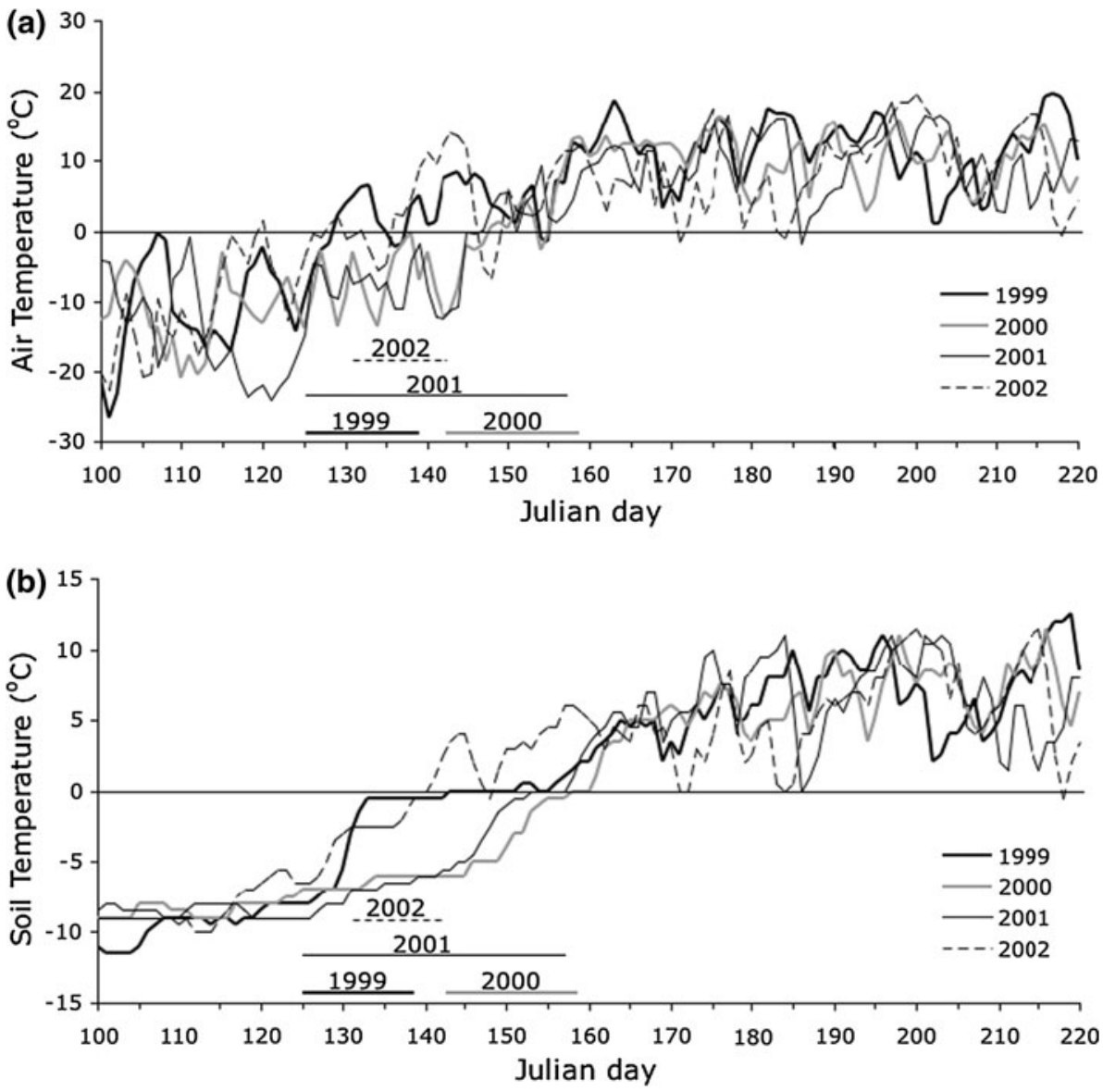
Table 3 Climatic data averaged from DOY 160-220 (the period of observation common to all years), from 1999 to 2002

\begin{tabular}{|c|c|c|c|c|c|c|c|c|}
\hline \multirow[t]{2}{*}{ Years } & \multirow[t]{2}{*}{$\mathrm{P}(\mathrm{mm})$} & \multirow[t]{2}{*}{$T_{\text {air }}\left({ }^{\circ} \mathrm{C}\right)$} & \multirow[t]{2}{*}{$T_{\text {soil }}\left({ }^{\circ} \mathrm{C}\right)$} & \multirow[t]{2}{*}{ GR $\left(\mathrm{J} / \mathrm{cm}^{2} /\right.$ day $)$} & \multicolumn{2}{|c|}{ Moisture content ${ }^{\mathrm{a}}(\mathrm{V} / \mathrm{V})$} & \multirow[t]{2}{*}{ PND } & \multirow[t]{2}{*}{ PDD } \\
\hline & & & & & Control & Treatment & & \\
\hline 1999 & $3.2(7.7)$ & $11.7(4.6)$ & $6.6(2.7)$ & $1,967(739)$ & $0.30(0.14)$ & $0.28(0.10)$ & $0.03(0.18)$ & $0.57(0.50)$ \\
\hline 2000 & $1.7(3.2)$ & $10.5(3.4)$ & $6.4(2.3)$ & $1,799(766)$ & $0.32(0.18)$ & $0.29(0.10)$ & $0.03(0.18)$ & $0.57(0.50)$ \\
\hline 2001 & $2.5(3.7)$ & $10.0(4.5)$ & $6.5(2.8)$ & $1,756(734)$ & $0.35(0.21)$ & $0.36(0.14)$ & $0.11(0.32)$ & $0.39(0.49)$ \\
\hline 2002 & $2.0(3.3)$ & $8.8(5.5)$ & $5.6(3.2)$ & $1,743(705)$ & $0.31(0.19)$ & $0.38(0.11)$ & $0.18(0.39)$ & $0.39(0.49)$ \\
\hline
\end{tabular}

Abbreviations for climatic variables defined in Table 2

Standard deviations are indicated in parentheses

a The CS615 was not calibrated for this soil type, and thus, reported values are relative estimates of volumetric water content

Table 4 Model of annual height increment (AHI) (Model 1) and seasonal growth rate (SGR) (Model 2)

\begin{tabular}{lcrcc}
\hline Factor & NDF & DDF & $F$ value & $p$ value \\
\hline Model 1 (AHI) & & & & \\
Treatment & 1 & 10 & 0.70 & 0.422 \\
Year & 3 & 164 & 5.43 & $\mathbf{0 . 0 0 1}$ \\
Treatment $\times$ year & 3 & 164 & 2.75 & $\mathbf{0 . 0 4 5}$ \\
Model 2 (SGR) & & & & \\
Year & 2 & 20 & 1.06 & 0.366 \\
DOY & 3 & 90 & 2.75 & $\mathbf{0 . 0 4 8}$ \\
Treatment $\times$ year & 2 & 20 & 0.96 & 0.398 \\
Treatment $\times$ DOY & 3 & 90 & 0.34 & 0.799 \\
Year $\times$ DOY & 6 & 90 & 4.53 & $\mathbf{0 . 0 0 1}$ \\
Treatment $\times$ year $\times$ DOY & 6 & 90 & 1.14 & 0.347 \\
\hline
\end{tabular}

$N D F$ nominator degree of freedom, $D D F$ denominator degree of freedom, $F$ Fisher $F$ test value, $P$ probability

Significant $p$ values are marked in bold

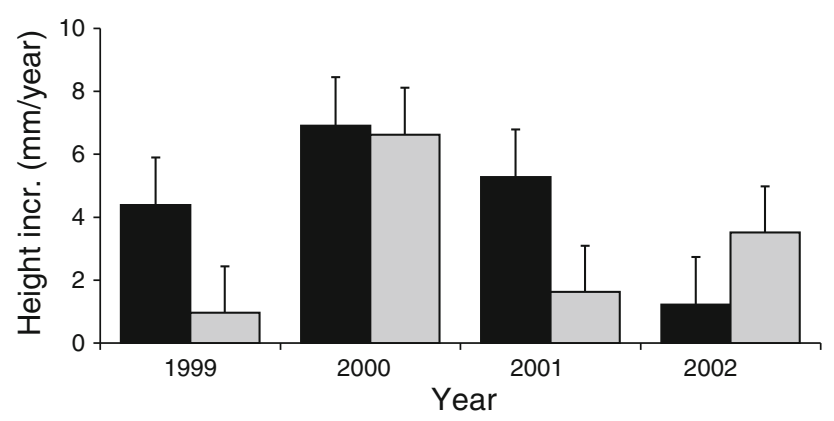

Fig. 2 Least square means annual height increment of Sphagnum from control plots (black bars) and snow removal plots (gray bars). Vertical bars represent one standard error

effect of soil temperature and the PDD on SGR, and a significant negative effect of global radiation on SGR (data not shown). The residual test of the effect of snow removal treatment on SGR indicated a marginally significant $(p=0.11)$ effect of snow removal, when taking into account effects of the set of climatic variables. Separate analyses for each treatment revealed a significant and

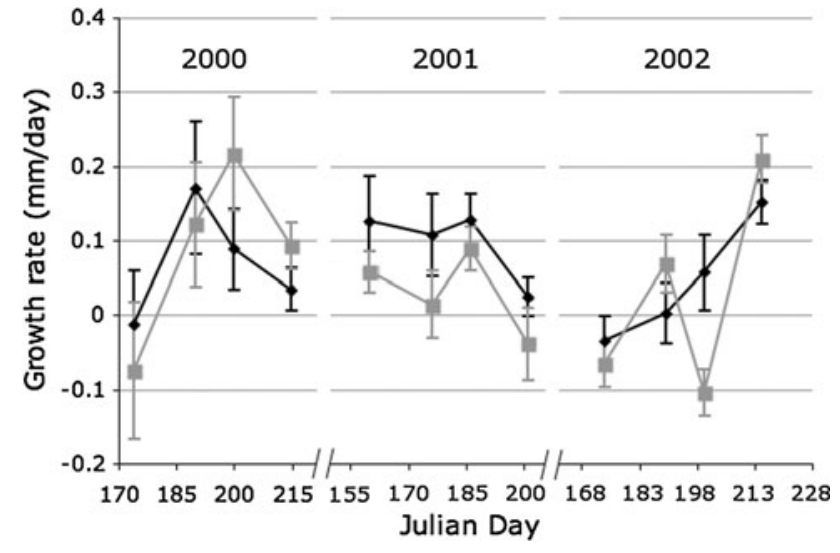

Fig. 3 Seasonal variation in height growth rate of Sphagnum individuals from control plots (diamonds, black line) and snow removal plots (squares, gray line). Vertical bars are standard errors

positive effect of soil temperature and the PDD on SGR in both control and treated plots $(p=0.027$ and 0.049, respectively; Table 5). While the effects of soil temperature were not significantly different between control and snow removal plots, the effect of PDD was significantly stronger in snow removal plots (Bonferroni-corrected $p=0.057)$. The effect of the proportion of days with negative mean temperature had a marginally significant effect on SGR, with a negative effect in the control plots $(p=0.074)$ and a positive effect in snow removal plots $(p=0.105)$. In the snow removal plots, there was also a significant negative effect of global radiation on SGR $(p=0.030$; Table 5).

\section{Discussion}

Annual height increments from control plots reported in the present study ranged from 1.2 to $7.1 \mathrm{~mm} / \mathrm{year}$. These values are within the range of annual height increments reported on S. angustifolium in Québec (Moore 1989) and other Sphagnum species measured in high latitude locations (Murray et al. 1989; Aerts et al. 1992; Gehrke 1998; 
Table 5 Effects of climate variables on SGR (Model 3) by treatment

\begin{tabular}{|c|c|c|c|c|c|c|c|c|c|}
\hline \multirow[t]{2}{*}{ Factor } & \multirow[t]{2}{*}{ DF } & \multicolumn{4}{|l|}{ Control } & \multicolumn{4}{|c|}{ Snow removal treatment } \\
\hline & & Estimate & Standard error & $t$ value & $p$ value & Estimate & Standard error & $t$ value & $p$ value \\
\hline GR & 1 & -0.009 & 0.007 & 1.24 & 0.282 & -0.046 & 0.014 & 3.28 & $\mathbf{0 . 0 3 0}$ \\
\hline Moisture & 1 & 0.004 & 0.004 & 1.07 & 0.345 & 0.004 & 0.014 & 0.30 & 0.781 \\
\hline$p$ & 1 & -0.002 & 0.006 & 0.31 & 0.775 & 0.006 & 0.007 & 0.90 & 0.417 \\
\hline PDD & 1 & 0.027 & 0.010 & 2.79 & 0.049 & 0.050 & 0.000 & 3.47 & 0.026 \\
\hline PND & 1 & -0.012 & 0.007 & 2.40 & 0.074 & 0.004 & 0.002 & 2.09 & 0.105 \\
\hline$T_{\text {air }}$ & 1 & 0.006 & 0.007 & 0.84 & 0.448 & -0.016 & 0.012 & 1.29 & 0.268 \\
\hline$T_{\text {soil }}$ & 1 & 0.018 & 0.005 & 3.41 & 0.027 & 0.035 & 0.012 & 2.80 & 0.049 \\
\hline
\end{tabular}

Estimates and standard errors are given for the centered and scaled variables

$D F$ degree of freedom, $t$ Student's $t$ test value, $p$ probability. (Abbreviations for climatic variables defined in Table 2)

Significant coefficients $(p$ value $<0.05)$ are marked in bold

Searles et al. 2002; Sonesson et al. 2002; Dorrepaal et al. 2004; Gunnarsson 2005).

The effect of lengthened growing season on the annual height growth increment of $S$. angustifolium was different by year, and the lengthened growing season was only marginally significantly different from the controls in 1999 and 2001. This marginal effect was due in part to low statistical power of the experiment; for three of the 4 years, growth was lowest on the lengthened growing season plots. Compared to the control plots, AHI decreased by 3.44 and $3.67 \mathrm{~mm}$ when growing season was lengthened in 1999 and 2001, respectively, representing 78.2 and $69.4 \%$ of the growth achieved in the control plots in those years. This decrease in growth may be related to Sphagnum exposure to low temperatures and high light during an extended period in 2001 and before and after a warm period in 1999 (Table 2; Fig. 1). These findings give support to our initial hypothesis that an increase in the growing season length may be detrimental to Sphagnum growth as a result of photoinhibition caused by the plants emerging from snow near the seasonal peak of solar irradiance. Previous studies have shown that freezing events induced a loss of gross photosynthesis in Polytrichum alpestre (Kennedy 1993) and photoinhibition on Grimmia antarctici which caused a reduction in growth (Lovelock et al. 1995). This idea is supported by our analysis of the seasonal growth response to climate that showed the proportion of days with freezing temperature had a negative (though not significant) impact on the seasonal growth rate (Fig. 3). Similarly, very low growth observed in 2002 in both control and lengthened growing season plots might be associated with a 3-day freezing period observed shortly after natural snowmelt (Fig. 1), when daily air temperature shifted from +14 to $-6.7{ }^{\circ} \mathrm{C}$ in 4 days. Although overall growth was inhibited in 2002, we observed higher growth rates in plots where growing season was lengthened, which may be associated with the warm period favoring height growth that occurred before the early freeze when control plots were still covered by snow.

While lengthening the growing season induced a large decrease in growth in 1999 and 2001, it did not in 2000 and 2002. The lowest temperatures reached after snow was removed were comparable for those years $\left(-10{ }^{\circ} \mathrm{C}\right.$ in 1999 and $-15^{\circ} \mathrm{C}$ in 2001 vs. $-13^{\circ} \mathrm{C}$ in 2000$)$, but the duration of the freezing period was much greater in 2001 than 2000 (Fig. 1), suggesting that the freezing period needs to be sufficiently long to induce significant effects. Vestgarden and Austnes (2009) showed for different Sphagnum-dominated vegetation types that the release of $\mathrm{CO}_{2}$ and dissolved organic carbon and nitrogen were increased during extended freezing periods. The marginally significant decrease of growth in plots where snow was removed in 1999 compared to 2000 cannot be related to the difference in duration of freezing period but to the freeze/thaw cycle that occurred during the spring treatment period in 1999. The warm period before the second freeze event may have induced the temporary restoration of photosynthetic activity and height growth and a subsequent decrease in frost hardiness in the moss (Cannell and Smith 1986; Rutten and Santarius 1992; Gu et al. 2008). One prediction of climate change for the arctic region is that weather patterns will become more unpredictable and there may be an increase in spring freeze/cycles (IPCC 2007). If these predictions are accurate, Sphagnum species will be more susceptible to reductions in growth and this may lead to their reductions in composition across the arctic.

Overall, a lengthened growing season did not significantly affect the seasonal dynamics of growth (i.e., the interaction between treatment and DOY of measurement was not significant, Table 4). Furthermore, our analysis showed that DOY and season had a significant effect on SGR, suggesting that there are common environmental variables driving the growth of individuals. Moreover, the seasonal dynamic was significantly different among years, 
as revealed by the significant interaction between the DOY and year; the pattern of the seasonal growth dynamic was not repeated between years. Therefore, seasonal growth in $S$. angustifolium seems less determined by ontogenetic controls than by environmental controls. This analysis supports the generally accepted but relatively untested postulate that mosses do not show an inherent growth rhythm, but rather grow actively whenever external conditions are favorable (e.g., Backeus 1988). Moss may need to accumulate a number of degree-days above zero before they can initiate growth which has been shown in vascular plant species in the arctic (Pop et al. 2000).

Negative growth rate values were recorded every year at different times during this study. Negative growth rates have been observed in previous studies on Sphagnum fuscum (Gehrke 1998; Sonesson et al. 2002) and Sphagnum magellanicum (Mulligan and Gignac 2002). These negative values could be related to dehydration during freezing or drought events (Proctor 2000, 2001; Lenne et al. 2010).

The analysis of growth response to climate revealed common climatic controls on the height growth of $S$. angustifolium in both treatments. This result is consistent with the absence of a significant interaction between treatment and DOY for SGR (Table 3). In both treated and untreated plots, Sphagnum growth was stimulated by elevated soil temperatures and dry conditions, a result that has been documented previously (Skre and Oechel 1981; Sonesson et al. 2002; Dorrepaal et al. 2004, 2006; Gunnarsson 2005; Breeuwer et al. 2008; Lang et al. 2009). However, we did not see a significant difference in soil moisture between treatments. This could be attributed to the fact that soil moisture was measured adjacent to our study on a nearby ecosystem experiment to minimize damage to the moss mats. But more likely, the lack of difference observed between manipulation and control was associated with the small size of our study plots ( $\sim 0.5 \mathrm{~m}$ in diameter), which allowed for the underlying permafrost to buffer the small plot areas (Starr et al. 2008). In addition, Dorrepaal et al. (2004) showed that in high latitude conditions, an increase of $0.9^{\circ} \mathrm{C}$ in summer temperature increased growth by 42-62\%, while Sonesson and colleagues (2002) found a negative effect of precipitation on length increment of Sphagnum and attributed it to leaching of nutrients resulting from the use of distilled water to enhance precipitations. This explanation, however, does not apply in our study, and we suggest that the positive impact of dry conditions resulted from the reduction of carbon uptake by temporary water saturation following rain events. During several rain events, the moss hollows were inundated with water. Olivas et al. (2010) showed reductions in physiological activity in a coastal arctic ecosystem associated with increased inundation.

The height growth of individuals within the lengthened growing season treatment was negatively correlated with global radiation (Table 5). This result is consistent with the studies of Harley et al. (1989) and Murray et al. (1989, 1993), who observed a decrease of maximum chlorophyll fluorescence in arctic and temperate mosses with increasing global radiation due to photoinhibition. Our snow removal treatment occurred near summer solstice, which exposed Sphagnum to high levels of radiation from clear skies and reflective snow. This in combination with low air temperatures may have lead to photoinhibition, which caused the decline in growth in the extended season plots (Lovelock et al. 1995).

Whereas most existing studies have examined the relationships between growth and climate on an annual time scale and/or have substituted space for time by comparing different sites (i.e., Backeus 1988; Callaghan et al. 1997; Gunnarsson 2005; Lang et al. 2009), we conducted, to our knowledge, the first multi-year analysis on a seasonal time scale at the same site. Lang et al. (2009) demonstrated that spatial and temporal scales strongly determined which environmental drivers correlated most with vegetation composition and diversity. In that study, only meso-environmental controls of growth were considered on plots located on comparable microsites. Comparisons of contrasting microsites could reveal the importance of additional environmental factors on height incremental growth in S. angustifolium and hence peat production. Therefore, we propose that additional studies are needed across the arctic to develop a better understanding of Sphagnum's response to a lengthened growing season. We also can conclude that with a lengthening of the growing season, Sphagnum mosses will be exposed to higher light quantities that may reduce their growth due to photoinhibition. This possible reduction in Sphagnum growth in the near future may have significant implications for peat production in tussock tundra ecosystems, but will need to be explored in more detail and over longer periods of study.

Acknowledgments This study was based in part on work supported by the National Science Foundation Office of Polar Programs under grants OPP 9321626, 9907185, 0806983 and 0806776 . We would like to thank Toolik Field Station staff for logistical support and Lorraine Ahlquist and Tracey Baldwin for help with field measurements. We thank the Arctic LTER for access to the Toolik meteorological data. Behzad Mortazavi provided comments on earlier drafts of this manuscript.

Open Access This article is distributed under the terms of the Creative Commons Attribution License which permits any use, distribution, and reproduction in any medium, provided the original author(s) and the source are credited.

\section{References}

Aerts R, Wallen B, Malmer N (1992) Growth-limiting nutrients in Sphagnum-dominated bogs subject to low and high atmospheric nitrogen supply. J Ecol 80:131-140 
Backeus I (1988) Weather variables as predictors of Sphagnum growth on a bog. Holarctic Ecol 11:146-150

Benoy GA, Cash K, Levesque L, McCauley E, Wrona F (2007) Antecedent snow conditions affect water levels and plant biomass of a fen in the southern boreal forest: results from an experiment using mesocosms. Boreal Env Res 12:501-513

Bliss LC, Matveyeva NV (1992) Circumpolar arctic vegetation. In: Chapin FS III, Jefferies RL, Reynolds JF, Shaver GR, Svoboda J (eds) Arctic ecosystems in a changing climate: an ecophysiological perspective. Academic Press Inc., San Diego, pp 59-91

Breeuwer A, Heijmans M, Robroek BJM, Berendse F (2008) The effect of temperature on growth and competition between Sphagnum species. Oecologia 156:155-167

Breeuwer A, Heijmans M, Gleichman M, Robroek BJM, Berendse F (2009) Response of Sphagnum species mixtures to increased temperature and nitrogen availability. Plant Ecol 204:97-111

Callaghan TV, Carlsson BA, Sonesson M, Temesvary A (1997) Between-year variation in climate-related growth of circumarctic populations of the moss Hylocomium splendens. Funct Ecol 11:157-165

Cannell MGR, Smith RI (1986) Climatic warming, spring budburst and frost damage on trees. J Appl Ecol 23:177-191

Chapin FS III, Zimov SA, Shaver GR, Hobbie SE (1996) $\mathrm{CO}_{2}$ fluctuation at high latitudes. Nature 383:585-586

Clymo RS (1970) The growth of Sphagnum: methods of measurement. J Ecol 58:13-49

Clymo RS, Hayward PM (1982) The ecology of Sphagnum. In: Smith AJE (ed) Bryophyte ecology. Chapman and Hall, London, pp 229-289

Dorrepaal E, Aerts R, Cornelissen JHC, Callaghan TV, van Logtestijn RSP (2004) Summer warming and increased winter snow cover affect Sphagnum fuscum growth, structure and production in a sub-arctic bog. Glob Change Biol 10:93-104

Dorrepaal E, Aerts R, Cornelissen JHC, Van Logtestijn RSP, Callaghan TV (2006) Sphagnum modifies climate-change impacts on subarctic vascular bog plants. Funct Ecol 20:31-41

Dorrepaal E, Toet S, van Logtestijn RSP, Swart E, van de Weg MJ, Callaghan TV, Aerts R (2009) Carbon respiration from subsurface peat accelerated by climate warming in the subarctic. Nature 460:616-619

Fekedulegn D, Hicks RR Jr, Colbert JJ (2003) Influence of topographic aspect, precipitation and drought on radial growth of four major tree species in an Appalachian watershed. Forest Ecol Manag 177:409-425

Galen C, Stanton ML (1995) Response of snowbed plant-species to changes in growing-season length. Ecology 76:1546-1557

Gehrke C (1998) Effects of enhanced UV-B radiation on productionrelated properties of a Sphagnum fuscum dominated subarctic bog. Funct Ecol 12:940-947

Gorham E (1991) Northern peatlands-role in the carbon-cycle and probable responses to climatic warming. Ecol Appl 1:182-195

Gu L, Hanson PJ, Mac Post W, Kaiser DP, Yang B, Nemani R, Pallardy SG, Meyers T (2008) The 2007 eastern us spring freezes: increased cold damage in a warming world? Bioscience $58: 253-262$

Gunnarsson U (2005) Global patterns of Sphagnum productivity. J Bryol 27:269-279

Gunnarsson U, Malmer N, Rydin H (2002) Dynamics or constancy in sphagnum dominated mire ecosystems? A 40-year study. Ecography 25:685-704

Harley PC, Tenhunen JD, Murray KJ, Beyers J (1989) Irradiance and temperature effects on photosynthesis of tussock tundra Sphagnum mosses from the foothills of the Philip Smith Mountains, Alaska. Oecologia 79:251-259

IPCC (2007) Climate change 2007: the physical science basis. Contribution of working group I to the Fourth Assessment
Report of the Intergovernmental Panel on Climate Change. Cambridge University Press, Cambridge

Kennedy AD (1993) Photosynthetic response of the antarctic moss Polytrichum-alpestre hoppe to low-temperatures and freezethaw stress. Polar Biol 13:271-279

Lang SI, Cornelissen JHC, Holzer A, ter Braak CJF, Ahrens M, Callaghan TV, Aerts R (2009) Determinants of cryptogam composition and diversity in Sphagnum-dominated peatlands: the importance of temporal, spatial and functional scales. J Ecol 97:299-310

Lenne T, Bryant G, Hocart CH, Huang CX, Ball MC (2010) Freeze avoidance: a dehydrating moss gathers no ice. Plant Cell Environ 33:1731-1741

Lovelock CE, Osmond CB, Seppelt RD (1995) Photoinhibition in the antarctic moss grimmia antarctici card when exposed to cycles of freezing and thawing. Plant Cell Environ 18:1395-1402

Moore TR (1989) Growth and net production of Sphagnum at 5 fen sites, Subarctic Eastern Canada. Can Can J Bot/Rev Can Bot 67:1203-1207

Mulligan RC, Gignac LD (2002) Bryophyte community structure in a boreal poor fen II: interspecific competition among five mosses. Can J Bot/Rev Can Bot 80:330-339

Murray KJ, Tenhunen JD, Kummerow J (1989) Limitations of Sphagnum growth and net primary production in the foothills of the Philip-Smith mountains, Alaska. Oecologia 80:256262

Murray KJ, Tenhunen JD, Nowak RS (1993) Photoinhibition as a control on photosynthesis and production of Sphagnum mosses. Oecologia 96:200-207

Myneni RB, Keeling CD, Tucker CJ, Asrar G, Nemani RR (1997) Increased plant growth in the northern high latitudes from 1981 to 1991. Nature $386: 698-702$

Oberbauer SF, Starr G, Pop EW (1998) Effects of extended growing season and soil warming on carbon dioxide and methane exchange of tussock tundra in Alaska. J Geophys Res 103: 29075-29082

Olivas PC, Oberbauer SF, Tweedie CE, Oechel WC, Kuchy A (2010) Responses of $\mathrm{CO}_{2}$ flux components of Alaskan coastal plain tundra to shifts in water table. J Geophys Res 115:G00I05. doi: 10.1029/2009JG001254

Overland JE, Spillane MC, Percival DB, Wang MY, Mofjeld HO (2004) Seasonal and regional variation of pan-arctic surface air temperature over the instrumental record. J Climate 17:32633282

Pop EW, Oberbauer SF, Starr G (2000) Predicting bud break in two arctic deciduous shrubs: Betula nana and Salix pulchra. Oecologia 124:176-184

Proctor MCF (2000) The bryophyte paradox: tolerance of desiccation, evasion of drought. Plant Ecol 151:41-49

Proctor M (2001) Patterns of desiccation tolerance and recovery in bryophytes. Plant Growth Regul 35:147-156

Robson TM, Pancotto VA, Flint SD, Ballare CL, Sala OE, Scopel AL, Caldwell MM (2003) Six years of solar UV-B manipulations affect growth of sphagnum and vascular plants in a tierra del fuego peatland. New Phytol 160:379-389

Rutten D, Santarius KA (1992) Age-related differences in frost sensitivity of the photosynthetic apparatus of 2 Plagiomnium species. Planta 187:224-229

Rydin H, Barber KE (2001) Long-term and fine-scale coexistence of closely related species. Folia Geobiol 36:53-61

Searles PS, Flint SD, Diaz SB, Rousseaux MC, Ballare CL, Caldwell MM (2002) Plant response to solar ultraviolet-b radiation in a southern South American Sphagnum peatland. J Ecol 90:704713

Skre O, Oechel WC (1981) Moss functioning in different taiga ecosystems in interior Alaska. I. Seasonal, phenotypic, and 
drought effects on photosynthesis and response patterns. Oecologia 48:50-59

Sonesson M, Carlsson BA, Callaghan TV, Halling S, Bjorn LO, Bertgren M, Johanson U (2002) Growth of two peat-forming mosses in subarctic mires: species interactions and effects of simulated climate change. Oikos 99:151-160

Starr G, Oberbauer SF, Pop EW (2000) Effects of lengthened growing season and soil warming on the phenology and physiology of Polygonum bistorta. Glob Change Biol 6:357-369

Starr G, Oberbauer SF, Ahlquist LE (2008) The photosynthetic response of Alaskan tundra plants to increased season length and soil warming. Arct Antarct Alp Res 40:181-191

Tedesco M, Brodzik M, Armstrong R, Savoie M, Ramage J (2009) Pan Arctic terrestrial snowmelt trends (1979-2008) from spaceborne passive microwave data and correlation with the arctic oscillation. Geophys Res Lett 36:6

Vestgarden LS, Austnes K (2009) Effects of freeze-thaw on C and N release from soils below different vegetation in a montane system: a laboratory experiment. Glob Change Biol 15:876-887

Wendler G, Shulski M, Moore B (2010) Changes in the climate of the Alaskan North Slope and the ice concentration of the adjacent Beaufort Sea. Theor Appl Clim 99:67-74

Wipf S, Rixen C (2010) A review of snow manipulation experiments in arctic and alpine tundra ecosystems. Polar Res 29:95-109

Zona D, Oechel WC, Richards JH, Hastings S, Kopetz I, Ikawa H, Oberbauer S (2011) Light-stress avoidance mechanisms in a Sphagnum-dominated wet coastal Arctic tundra ecosystem in Alaska. Ecology 92:644 